\title{
Developmental Association of Palatal Dimensions and Palatal Rugae Characteristics in Angle's Classes I, II and III of Malocclusion
}

\author{
Asociación de Desarrollo de las Dimensiones Palatinas y las Características \\ de las Rugas Palatinas en las Clases I, II y III de Maloclusión de Angle
}

Ibrahim Alshahrani' ${ }^{1}$; Sadatullah Syed²; Ali Azhar Dawasaz ${ }^{2}$;

Rafi Ahmad Togoo'; Mohamed Khaled Addas ${ }^{3}$ \& Asmaa Assaf ${ }^{4}$

\begin{abstract}
ALSHAHRANI, I; SYED, S.; DAWASAZ, A. A.; TOGOO, R. A.; ADDAS, M. K. \& ASSAF, A. Developmental association of palatal dimensions and palatal rugae characteristics in Angle's classes I, II and III of malocclusion. Int. J. Morphol., 37(2):744-751, 2019.

SUMMARY: During development, bony changes in the palate are reflected in the palatal rugae. Therefore, we hypothesized that the palatal dimensions (PD) influence the shape and number of palatal rugae (PR). The objectives were to record the palatal rugae characteristics (PRC) and palatal dimensions (intercanine distance (ICD), intermolar distance (IMD), palatal height (PH) and palatal area (PA) in Classes I, II and III malocclusion patients and investigate their interrelationship, and statistically examine the possibility of predicting PRC with the PD. Four hundred eighty-one pre-orthodontic study casts of healthy patients with normal palate anatomy were grouped as Classes I, II and III and scanned using 3D cast scanner. The PRC, ICD, IMD, PH, and PA were recorded digitally using 3D enabled software. The data was statistically analyzed. A strong statistically significant difference was observed between PA and number of straight and wavy rugae. ICD and the number of straight rugae were also related. A weak correlation exists between malocclusion classes and PA. The remaining rugae characteristics did not exhibit any relation with palatal dimensions. PA is positively related to the number of straight rugae and negatively related to the number of wavy rugae. Bigger palates have more straight rugae and less number of wavy rugae. A weak correlation between PA and Angle's class I malocclusion exists. We also propose that PA has a developmental association with the number and shape of PR.
\end{abstract}

KEY WORDS: Palatal rugae; Malocclusion; Palate; Angle's class I; Angle's class II; Angle's class III.

\section{INTRODUCTION}

Palatal rugae (PR) also referred to as plicae palatinae transversae, rugae palatinae or simply palatal ridges are stable, transverse mucosal ridges present in the anterior part of the hard palate. Their total number is species specific and their pattern is individual specific (Schultz, 1949; Schultz et al., 1958) to the extent that in humans they are akin to fingerprint pattern in confirming identity (Hermosilla et al., 2009). They assist in mastication by creating surface friction to hold the bolus in place and play a role in tasting food via several intraepithelial sensory structures (Buchtová et al., 2003). In the human embryo, the first ruga is distinguished at $32 \mathrm{~mm}$ Crown-rump length (CRL) at about the same time when the palatine shelves fuse (Thomas, 1984). The palatal pattern orientation and the palatal rugae characteristics (PRC) on either side of the midpalatine raphe are established between the $12^{\text {th }}$ and $14^{\text {th }}$ week of intrauterine life (Bansode \& Kulkarni, 2009). Unlike humans, PR is noticed earlier in rodents and the rugal analgen are believed to stiffen the palatal shelves and aid in horizontalizing it above the dorsum of the tongue. Therefore, PR plays an important function, both, prenatally and postnatally.

The development of PR continues along with the growth of the palate characterized by oscillation of cellular events including proliferation, apoptosis, cell differentiation and cell migration in the involved tissues. This proliferation and inhibition process is responsible for the periodic and asymmetric inter-positioning of the rugae. The proliferating

\footnotetext{
${ }^{1}$ Department of Pediatric Dentistry and Orthodontic Sciences, King Khalid University College of Dentistry. Abha. Saudi Arabia.

${ }^{2}$ Department of Diagnostic Sciences and Oral Biology, King Khalid University College of Dentistry. Abha. Saudi Arabia.

${ }^{3}$ Department of Prosthodontic Sciences, King Khalid University College of Dentistry. Abha. Saudi Arabia.

${ }^{4}$ Pediatric Dentistry Resident, King Khalid University College of Dentistry. Abha. Saudi Arabia.

This work was supported by King Khalid University College of Dentistry Maxillofacial Research Center (Research Project Number: MRMC 01-017003).
} 
cells are present mainly between the developing rugal region and in its thickened epithelium (Takanosu et al., 2002). Six stages of individual rugae development described by Peterková et al. (1987) are: 1) The rugal anlage - epithelial thickening and dipping into adjacent mesenchyme. 2) The primitive ruga - basement membrane leveling and projection of epithelium above the surface. 3) Mesenchymal condensation beneath the top of the rugae. 4) The rugal core - formation of bulged fibrous stroma beneath the rugae covered with thinning epithelium. 5) The definitive ruga epithelium of uniform thickness like the one covering the inter-rugal areas, initial keratinization. 6) The adult ruga.

The primary palate acts a molecular signaling center in the development of secondary palate (Smith et al.,2013). This leads to a dome-shaped area bound by teeth forming the roof of the mouth. During development, the underlying bony changes of the palate are reflected in rugal changes (Enlow \& Bang, 1965). Therefore, it can be hypothesized that the shape and size of the palate have a direct bearing on the shape and number of PR. The size of the palate or the palatal dimensions (PD) in a fully formed palate is measured as the intercanine distance (ICD), interpremolar distance, intermolar distance (IMD) and height of the palate vault (PH). The palatal dimensions and palatal height differ in males and females and in different types of malocclusions (Nahidh et al., 2012; Zarringhalam, 2004). Nahidh et al. reported large palatal dimensions in Angle's Class I and II males and Class III females. Likewise, Zarringhalam reported a bigger $\mathrm{PH}$ in males than in females in the three Angle's classes of malocclusion. To the best of our knowledge, the area of the palate has not been studied so far as a measure of palatal dimension.

In this study, we measured the palatal area (PA) using 3D images of the palate and 3D software. This was done primarily to find out whether the shape and number of rugae have an association with PA and other palatal dimensions. The specific objectives of the study were to record the PRC and PD (ICD, IMD, PH, and PA) in Classes I, II and III malocclusion patients and investigate their interrelationship. Another objective was to statistically examine the possibility of predicting PRC with the PD. We also aimed at exploring the developmental association of PRC and PD by reviewing the literature.

\section{MATERIAL AND METHOD}

The study was conceptualized, registered and ethical approval obtained in January 2018 (SRC/ETH/2017-18/063). Observational, cross-sectional design was employed to collect 481 study casts from King Khalid University College of Dentistry Clinics. Non-probability/purposive sampling was used to select all available, good condition, pre-treatment casts of Saudi patients that started orthodontic treatment between November 2015 to February 2018. The casts were divided into three groups according to Angle's classification of Malocclusion (Classes I, II and III). The age, sex, nationality, intraoral/extraoral condition, and Angle's classification were noted from the patient file records. The patients were between 21 to 31 years, reported systemically normal without any history of orthodontic or surgical treatment of the palate. They were dentate with all the incisors, canines, premolars, first molars present in the maxillary arch. Casts of patients with fixed or removable prosthesis and torus palatinus were not included.

The selected casts were scanned using Sirona inEos $\mathrm{X} 5^{\circledR} 3 \mathrm{D}$ cast scanner. Single examiner viewed the palate area of the $3 \mathrm{D}$ images on the computer screen using Minimagic 2.0 software (Materialise, Technologielaan 15,3001 Leuven Belgium) and recorded the PRC using modified Brinon classification (Table I) (Herrera et al., 2017). ICD was measured as the distance between canine cusp tips or estimated cusp tips in cases of wear facets (Rosseto et al., 2009). IMD was measured as the distance between mesiopalatal cusp tips of maxillary first molars or estimated cusp tips in cases of wear facets (Rosseto et al.). PH was taken at the level of mesiopalatal cusp tips of the right and left maxillary first molars and measured to the deepest point of the palate on the midpalatine raphe, perpendicular to the posterior occlusal plane.

Table I. Classification of Palatal rugae (Herrera et al., 2009).

\begin{tabular}{lcc}
\hline \multicolumn{1}{c}{ Ruga Characteristic } & Number \\
\hline Straight & 1 \\
Warved & 2 & \\
Ramified & 3 \\
Circular & 5
\end{tabular}

All the cast images were oriented using global coordination system in Rhino 5 software (McNeel Europe Roger de Flor, 32-34 Barcelona 08018 Spain) so that the Xaxis, Y-axis, and Z-axis are aligned (Fig. 1). PA calculation 
was done by extracting the palate using Meshmixer software (Version 3 Autodesk Inc. USA). A line was drawn starting from the distal contact of the first upper molar extending anteriorly along the free gingival margin up to the distal contact of first opposite side first molar and back to the starting point in a straight line, thus making a closed loop. The selected closed loop area was raised 11 millimeters from the original meshwork using extract command (Fig. 2). The area of this extracted palate was calculated using Rhino 5 software. ICD and IMD were measured using thedistance' tool of Minimagic 2.0 software (Materialise, Technologielaan 15, 3001 Leuven Belgium) in frontal view between the respective points on the teeth as described earlier (Fig. 3). A line was drawn connecting the tips of the mesiopalatal cusps of upper first molars and two more lines were drawn from both ends of the first line towards the deepest point on the palate thus forming a triangle. $\mathrm{PH}$ was calculated from the values of this triangle and applying the triangle formula in Microsoft Office Excel 2016 (USA) (Fig. 4). Al the analysis was done between February and April 2018.

Inferential statistics were done by comparing the means of ICD, IMD PH, and PA in relation to the number of different PRC's in the three study groups using one-way ANOVA. The level of significance was set at 0.05 . Subsequently, LSD post hoc was carried out for the groups that were statistically significant. Pearson's Correlation test was done to estimate the correlation between the groups. Linear regression analysis was done to quantify the strength of the relationship between the dependent (PRC) and independent (palatal dimensions) variables.

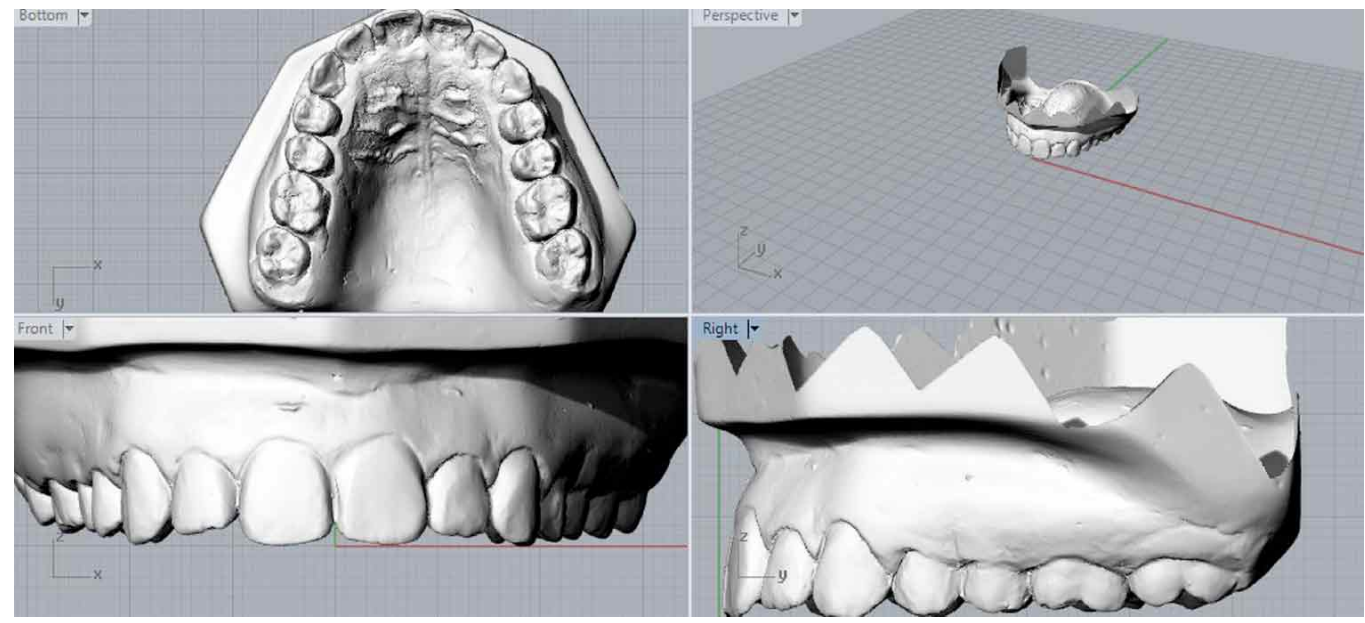

Fig. 1. Alignment of casts according to X-axis, Y-axis, and Z-axis.

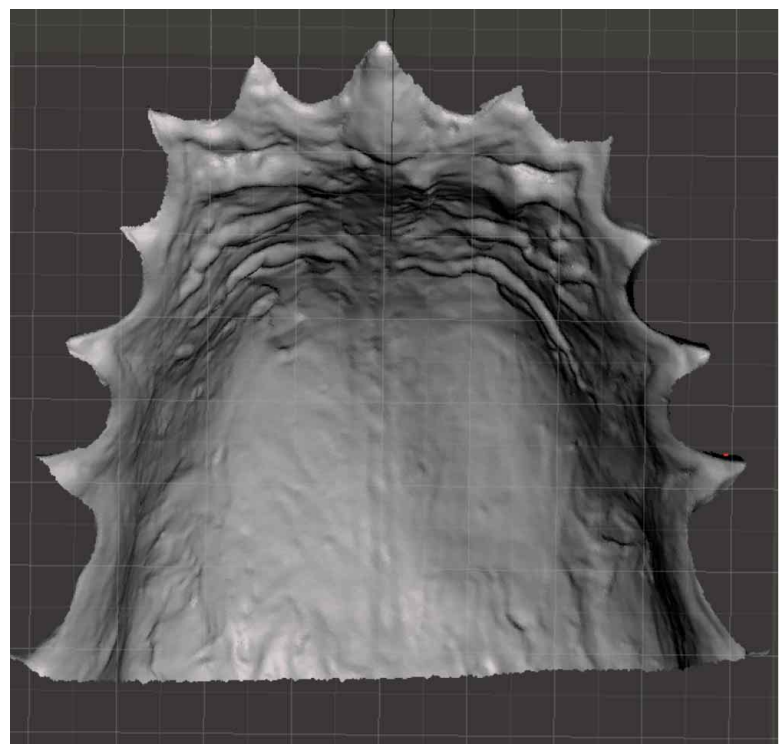

Fig. 2. Palate area extracted from the cast.

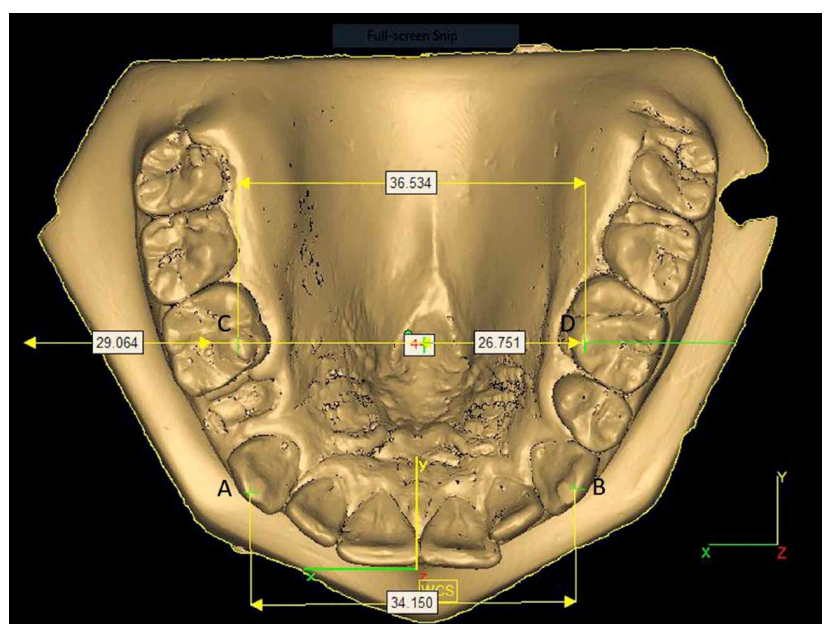

Fig. 3. Intercanine distance measured from the canine cusp tip (A) to the opposite side canine cusp tip (B). Intermolar distance measured from the mesiopalatal cusp tip of the first molar (C) to opposite side mesiopalatal cusp tip of the first molar (D). 


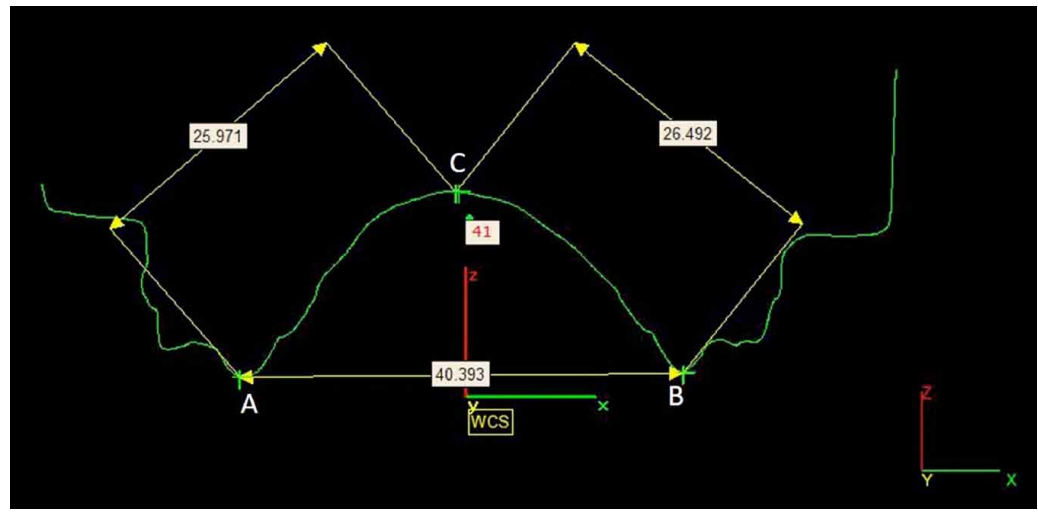

Fig. 4. A line drawn from the mesiopalatal cusp tip of the first molar (A) to opposite side mesiopalatal cusp tip of the first molar (B). Another line is drawn from point A to the deepest part on the palate vault $(\mathrm{C})$. Similarly, a line is drawn from point $\mathrm{B}$ to the point $\mathrm{C}$ making a triangle

\section{RESULTS}

Palatal Rugae Characteristics. Four images were left out owing to unsatisfactory image quality leaving 477 3D images for analysis. In modified Brinon classification (Herrera et al.), we recorded 'other' characteristic including papillary and branch type of characteristics.
Mean ICD, IMD, PH and PA values for the study casts were $33.18( \pm 2.8), 37.23( \pm 3.41), 20.51( \pm 2.89)$, and 1428.25 ( \pm 198.24$)$ respectively. We did not find 'Point' shape ruga in any of the casts examined in the study. The most common PRC was wavy (34.41\%) followed by

Table II. Comparison of straight palatal rugae and different palatal dimension groups by one-way ANOVA

\begin{tabular}{llccccc}
\hline Straight Palatal Rugae & Sum of Squares & df & Mean Square & F & Sig. \\
\hline \multirow{2}{*}{ IMD } & Between Groups & 191.318 & 9 & 21.258 & 1.856 & .056 \\
& Within Groups & 5347.474 & 467 & 11.451 & & \\
& Total & 5538.792 & 476 & & & \\
& Between Groups & 147.305 & 9 & 16.367 & 2.118 & $.027^{*}$ \\
ICD & Within Groups & 3608.543 & 467 & 7.727 & & \\
& Total & 3755.848 & 476 & & & \\
& Between Groups & 102.865 & 9 & 11.429 & 1.374 & .197 \\
PD & Within Groups & 3883.852 & 467 & 8.317 & & \\
& Total & 3986.717 & 476 & & & \\
\multirow{2}{*}{ PA } & Between Groups & 7662520.482 & 9 & 851391.165 & 35.999 & $.000^{*}$ \\
& Within Groups & 11044824.321 & 467 & 23650.587 & & \\
\hline
\end{tabular}

*Statistically significant at $5 \%$ level. I[Different characters in the superscript mean statistically significant difference by LSD post hoc test.

Table III. Comparison of wavy palatal rugae and different palatal dimension groups by one-way ANOVA.

\begin{tabular}{|c|c|c|c|c|c|c|}
\hline \multicolumn{2}{|c|}{ Wavy Palatal Rugae } & Sum of Squares & $\mathrm{df}$ & Mean Square & $\mathrm{F}$ & Sig. \\
\hline \multirow{3}{*}{ IMD } & Between Groups & 107.855 & 8 & 13.482 & 1.162 & .321 \\
\hline & Within Groups & 5430.937 & 468 & 11.605 & & \\
\hline & Total & 5538.792 & 476 & & & \\
\hline \multirow{3}{*}{ ICD } & Between Groups & 45.510 & 8 & 5.689 & .718 & .676 \\
\hline & Within Groups & 3710.338 & 468 & 7.928 & & \\
\hline & Total & 3755.848 & 476 & & & \\
\hline \multirow{3}{*}{ PD } & Between Groups & 87.748 & 8 & 10.968 & 1.317 & .233 \\
\hline & Within Groups & 3898.969 & 468 & 8.331 & & \\
\hline & Total & 3986.717 & 476 & & & \\
\hline \multirow{3}{*}{ PA } & Between Groups & 1865295.803 & 8 & 233161.975 & 6.479 & $.000^{*}$ \\
\hline & Within Groups & 16842049.000 & 468 & 35987.284 & & \\
\hline & Total & 18707344.802 & 476 & & & \\
\hline
\end{tabular}

*Statistically significant at $5 \%$ level. IDifferent characters in the superscript mean statistically significant difference by LSD post hoc test. 
straight (27.5\%), curve (14.93\%), ramified (9.24\%), complex $(8.78 \%)$ and annular $(5.11 \%)$. A strong statistically significant difference of means was observed between the values of PA and number of straight and wavy rugae. ICD and the number of straight rugae were also statistically related (Tables II and III). These figures were further justified by Pearson's Correlation test, which revealed a significant positive relation between straight rugae and the PA and a significant negative

Table IV. Comparison of straight and wavy palatal rugae characteristics and different palatal dimension by Pearson's Correlation.

\begin{tabular}{llrrrc}
\hline & & IMD & ICD & PD & PA \\
\hline \multirow{4}{*}{ Straight } & Pearson Correlation & .083 & .051 & $-.009-$ & $.555^{* *}$ \\
& Sig. (2-tailed) & .072 & .270 & .838 & .000 \\
& $\mathrm{~N}$ & 477 & 477 & 477 & 477 \\
\multirow{4}{*}{ Wavy } & Pearson Correlation & $-.035-$ & $-.029-$ & .027 & $-.233-* *$ \\
& Sig. (2-tailed) & .444 & .529 & .560 & .000 \\
& $\mathrm{~N}$ & 477 & 477 & 477 & 477 \\
\hline \multirow{2}{*}{$* *$ Correlation is significant at the 0.01 level (2-tailed). } & *. Correlation is significant at
\end{tabular}
the 0.05 level (2-tailed).

Table V. Linear regression analysis with PA, PD, ICD and IMD as predictors.

\begin{tabular}{lcccc}
\hline Model & $\mathrm{R}$ & $\mathrm{R}$ Square & Adjusted R Square & Std. Error of the Estimate \\
\hline Straight & $.556^{\mathrm{a}}$ & .310 & .304 & 1.809 \\
Wavy & $.237 \mathrm{a}$ & .056 & .048 & 2.020 \\
\hline
\end{tabular}

a. Predictors: (Constant), PA, PD, ICD, IMD

Table VI. Mean values of ICD, IMD, PD and PA in Class 1, 2, and 3 malocclusion.

\begin{tabular}{lcccc}
\hline$\#$ & ICD & IMD & PD & PA \\
\hline Class 1 & $33.02( \pm 2.8)$ & $37.09( \pm 3.3)$ & $20.76( \pm 3.1)$ & $1453( \pm 195.4)$ \\
Class 2 & $33.11( \pm 2.7)$ & $37.18( \pm 3.4)$ & $20.34( \pm 2.7)$ & $1500( \pm 203.4)$ \\
Class 3 & $33.68( \pm 2.8)$ & $37.66( \pm 3.5)$ & $20.51( \pm 2.87)$ & $1498( \pm 183.2)$ \\
\hline
\end{tabular}

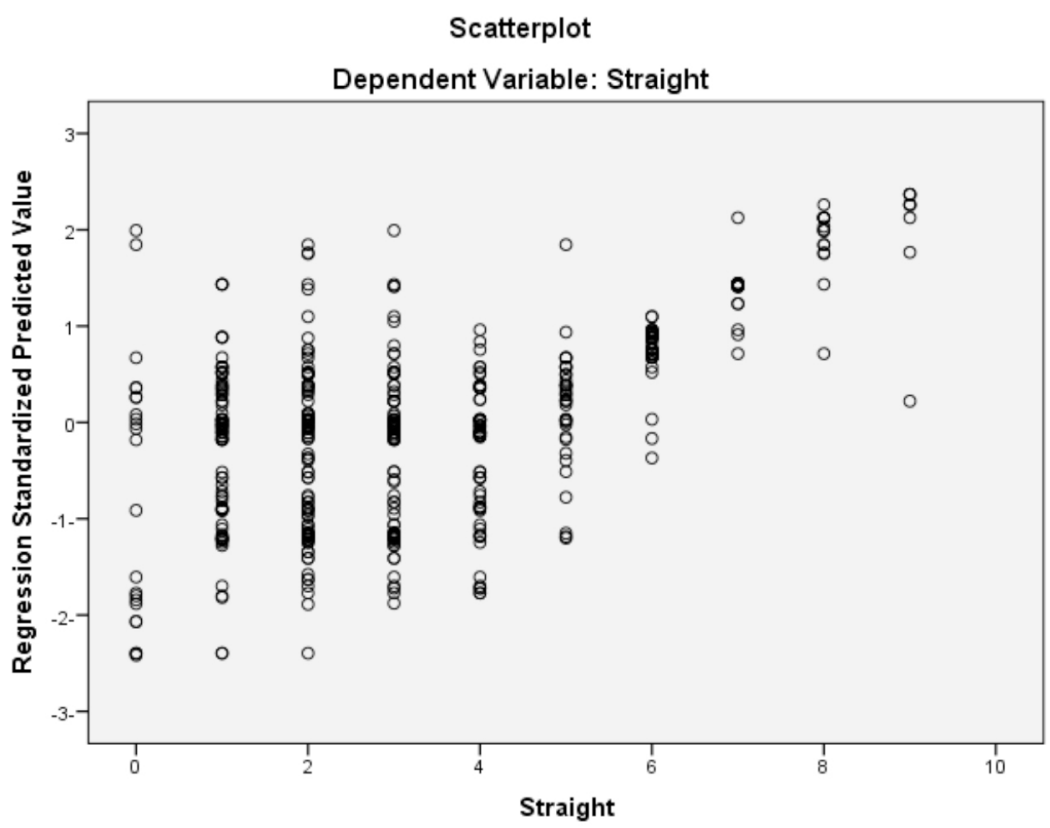

Fig. 5. Scatterplot with straight rugae as the dependent variable. relation between wavy rugae and PA (Table IV). Likewise, Scatter plots (Figs. 5 and 6) shows straight linearity, positive anch, annular and other rugae did not exhibit any statistical relation with any of the evaluated palatal dimensions.

Angle's Malocclusion. Mean ICD, IMD PH and PA values for Classes I, II and III groups are shown in Table VI. ANOVA showed an insignificant difference between Angle's Classes I, II, III malocclusions and ICD, IMD and MD. However, a weak correlation exists between malocclusion classes and palatal area (Table VII).

\section{DISCUSSION}

We have observed a highly significant statistical correlation between straight ruga, wavy ruga, and PA. Straight ruga is positively correlated to PA, implicating that bigger PA will result in more number of PR. The rugae seem to stretch out straight and increase in number when the area of the palatal bone beneath them is more. One can imagine that the rugae are originally straight ridges and they tend to curve and undulate under space duress. The opposite is true for wavy rugae, it is negatively correlated to PA. Smaller PA will result in less number of PR. Curve, wavy, ramified and other types of rugae shape are not related to PA. Charles et al. (2007) demonstrated various anomalies in eda mutant mice compared to wild-type mice, which mainly had straight and wavy rugae. In accordance with their findings, we propose that straight and wavy are the only actual shapes of PR, ramified and other polymorphic types can be phenotypic variables or anomalies. Most common type of mammalian PR, other than humans, is straight ruga. It can be possible that evolutionary changes in the size of the jaws and palate of humans have led to the formation of various shapes of rugae other than straight rugae. Regression analysis showed that PA had more chance of predicting the number of straight rugae than wavy rugae. 


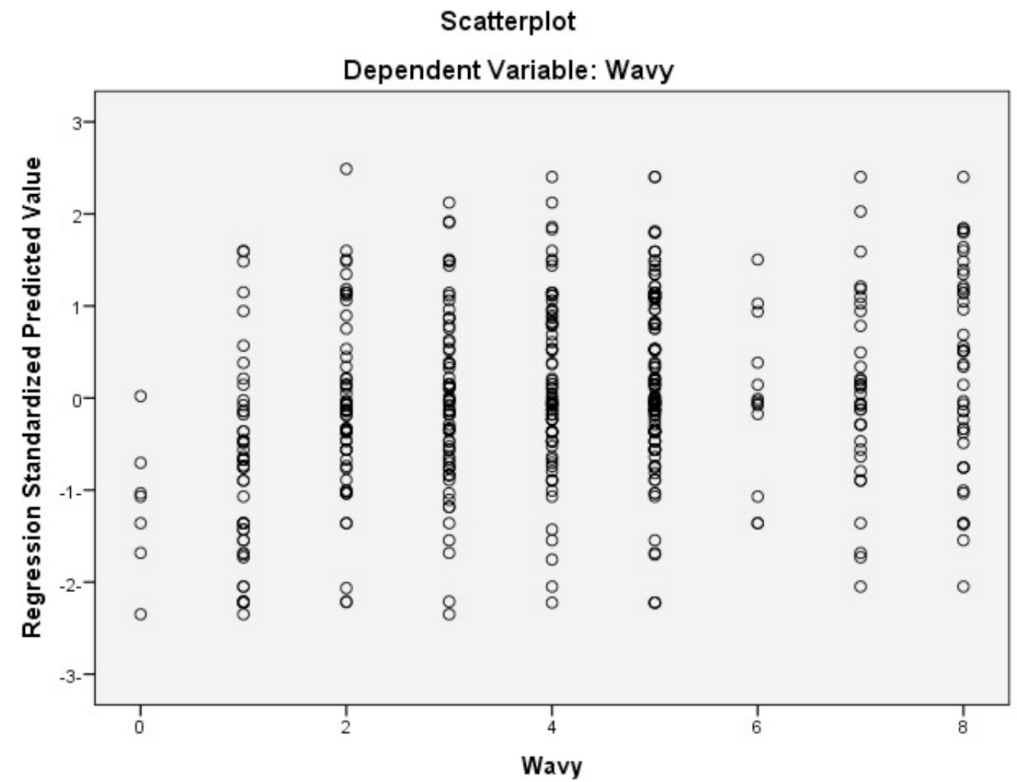

Fig. 6. Scatterplot with wavy rugae as the dependent variable

Table VII. Comparison of Angles Class 1, 2 and 3 malocclusion and different palatal dimension by Pearson's Correlation.

\begin{tabular}{llccccc}
\hline & \multicolumn{5}{c}{ Correlations } \\
& Class & IMD & ICD & PD & PA \\
\hline \multirow{3}{*}{ Class } & Pearson Correlation & 1 & .052 & .073 & $-.040-$ & $.091^{*}$ \\
& Sig. (2-tailed) & & .260 & .112 & .381 & .047 \\
& $\mathrm{~N}$ & 477 & 477 & 477 & 477 & 477 \\
\hline *. Correlation is significant at the 0.05 level (2-tailed). & $* *$. Correlation is significant at the 0.01 level (2-tailed).
\end{tabular}

Straight rugae are statistically related to ICD too, although the significance was very weak. IMD and PH had no relation to any of the rugae characteristics. Overall, other than PA, rugae characteristics are not influenced by any of the other palatal dimensions evaluated in our study. Similarly, there was no significant relationship between the Angle's Classes I, II and III malocclusion and the ICD, IMD, and PH. These results are in contrast with the findings of Zarringhalam, Al-Sayagh (2011) and Buschang et al. (1994). Zarringhalam reported a difference of palatal height in classes I and classes III malocclusion. Al-Sayagh too reported differences in palatal dimensions among different types of malocclusions. Another notable finding from our results is that Class I malocclusion is related to the palatal area, albeit weakly.

Based on Sakamoto et al. (1991) observations the formation of rugae variants in experimental animals is linked to abnormal epithelial-mesenchymal interaction which is speculated to be controlled by nerve fibers that appear at the time of rugal formation. Like other mesenchymal and epithelial structures, PR exhibit Shh (Sonic hedgehog) expression at an early stage of their development (Rice et al., 2006). It is a crucial signal that not only governs palatal growth but it is also pivotal in controlling the spatial patterning of PR (Lee et al., 2011). Interestingly, Shh expression is restricted to palatal rugae (Bitgood \& McMahon, 1995) and rugae function as Shh signaling centers (Welsh O'Brien, 2009). Underexpression of Shh leads to facial clefting and malformations of other frontonasal and maxillary process derived facial structures, while overexpression of Shh resulted in hypertelorism (Hu \& Helms, 1999). Altered expression of Shh leads to abnormal rugae patterning resulting in spotted shaped PR (Lee et al.). Therefore, Shh is regarded as the key player controlling the development of palate and its associated structures. Based on this argument the development of palate and PR seem to be interconnected, one affecting the other and vice versa. Hence, to assume that palatal dimensions have a developmental association with the number and shape of PR will not be wrong. 
Working with 3D images and software was a huge advantage in our study. It was possible to record the various distances in millimeters up to three decimal places. This was possible only because of the various $3 \mathrm{D}$ software that were used. However, our study was not free from limitations. We did not use subdivisions for Angle's classification, and in hindsight, this did not matter much since there was no significant relation with the malocclusion classification groups. ICD and IMD were not measured from the free gingival margin since the gingival condition of the patients were not known. Instead, canine cusp tip and the tip of the mesiopalatal cusp of the first molar were used. The drawback of using these cusp tips for ICD and IMD is that it is possible to record incorrect values in cases where canines and first molars are severely malposed. Another limitation with these cusp tips arises when the teeth are severely attrited. Although we used 3D software for measuring palatal dimensions, it is not easy to determine the accurate height of the palate vault as it can lie anywhere anteroposteriorly along the midpalatine raphe. To counter this issue we measured the deepest part of the palate in the section near the mesiopalatal cusp of the maxillary first molar.

In conclusion, we found that the palatal area is related to the number of straight rugae and inversely related to wavy rugae. In addition, Angle's class 1 malocclusion is weakly related to the palatal area. We also propose that the area of the palate has a developmental association with the number and shape of PR

\section{ACKNOWLEDGMENTS}

We are extremely grateful to King Khalid University College of Dentistry Maxillofacial Research Center for financially supporting the study [Project Number: MRMC 01-017-003, the Year 2018].

ALSHAHRANI, I; SYED, S.; DAWASAZ, A. A.; TOGOO, R. A.; ADDAS, M. K. \& ASSAF, A. Asociación del desarrollo de las dimensiones palatinas y las características de las rugas palatinas en las clases 1, 2 y 3 de maloclusión de Angle. Int. J. Morphol., 37(2):744-751, 2019.

RESUMEN: Durante el desarrollo, los cambios óseos en el paladar se reflejan en las rugas palatinas. Por lo tanto, planteamos la hipótesis de que las dimensiones palatinas influyen en la forma y el número de las rugas palatinas. Los objetivos fueron registrar las características de las rugas palatinas y las dimensiones palatales (distancia intercanina, distancia intermolar, altura palatina y área palatina) en pacientes con maloclusión de clases I, II y III e investigar su interrelación, y examinar estadísticamente la posibilidad de predecir las características de las rugas palatinas con las dimensiones palatinas. Cuatrocientos ochenta y un estudios pre-ortodónticos de pacientes sanos con anatomía normal del paladar se agruparon como Clases I, II y III y se escanearon con un escáner de emisión 3D. La distancia intercanina, distancia inter molar, altura palatina y área palatina se registraron digitalmente utilizando el software 3D. Los datos se analizaron estadísticamente. Se observó una diferencia estadísticamente significativa entre la altura palatina y el número de rugas rectas y onduladas. Se registró también la distancia intercanina y el número de rugas rectas. Existe una correlación débil entre las clases de maloclusión y la altura palatina. Las características restantes de las rugas palatinas no mostraron ninguna relación con las dimensiones palatinas. El área palatina está relacionada positivamente con el número de rugas rectas y negativamente relacionada con el número de rugas onduladas. Los paladares más grandes tienen más rugas rectas y menor cantidad de rugas onduladas. Existe una correlación débil entre el área palatina y la clase I de maloclusión de Angle. También proponemos que el área palatina tiene una asociación de desarrollo con el número y la forma de rugas palatinas.

PALABRAS CLAVE: Rugas palatinas; Maloclusión; Paladar; Clase I de Angle ; Clase II de Angle; Clase III de Angle.

\section{REFERENCES}

Al-Sayagh, N. M. The relationship of palatal dimensions for Iraqi adolescents with different dental angle classifications. Al-Rafidain Dent. J., 11(2):251-9, 2011.

Bansode, S. C. \& Kulkarni, M. M. Importance of palatal rugae in individual identification. J. Forensic Dent. Sci., 1(2):77-81, 2009.

Bitgood, M. J. \& McMahon, A. P. Hedgehog and Bmp genes are coexpressed at many diverse sites of cell-cell interaction in the mouse embryo. Dev. Biol., 172(1):126-38, 1995.

Buchtová, M.; Tichy, F.; Putnová, I. \& Mísek, I. The development of palatal rugae in the European pine vole, Microtus subterraneus (Arvicolidae, Rodentia). Folia Zool., 52(2):127-36, 2003.

Buschang, P. H.; Stroud, J. \& Alexander, R. G. Differences in dental arch morphology among adult females with untreated Class I and Class II malocclusion. Eur. J. Orthod., 16(1):47-52, 1994.

Charles, C.; Pantalacci, S.; Peterkova, R.; Peterka, M.; Laudet, V. \& Viriot, L. Disruption of the palatal rugae pattern in Tabby (eda) mutant mice. Eur. J. Oral Sci., 115(6):441-8, 2007.

Enlow, D. H. \& Bang, S. Growth and remodeling of the human maxilla. Am. J. Orthod., 51:446-64, 1965.

Hermosilla, V. V.; San Pedro, V. J.; Cantin, L. M. \& Suazo, G. I. C. Palatal rugae: systematic analysis of its shape and dimensions for use in human identification. Int. J. Morphol., 27(3):819-25, 2009.

Herrera, L. M.; Strapasson, R. A.; Mazzilli, L. E. \& Melani, R. F. Differentiation between palatal rugae patterns of twins by means of the Briñón method and an improved technique. Braz. Oral Res., 31:e9, 2017.

Hu, D. \& Helms, J. A. The role of sonic hedgehog in normal and abnormal craniofacial morphogenesis. Development, 126(21):4873-84, 1999.

Lee, J. M.; Miyazawa, S.; Shin, J. O.; Kwon, H. J.; Kang, D. W.; Choi, B. J.; Lee, J. H.; Kondo, S.; Cho, S. W. \& Jung, H. S. Shh signaling is essential for rugae morphogenesis in mice. Histochem. Cell Biol., 136(6):663-75, 2011.

Nahidh, M.; Al-Khawaja, N. F. K. \& Ghazi, A. Palatal dimensions in different occlusal relationships. J. Baghdad Coll. Dent., 24(1):116-20, 2012. 
ALSHAHRANI, I; SYED, S.; DAWASAZ, A. A.; TOGOO, R. A.; ADDAS, M. K. \& ASSAF, A. Developmental association of palatal dimensions and palatal rugae characteristics in Angle's classes I, II and III of malocclusion. Int. J. Morphol., 37(2):744-751, 2019.

Peterková, R.; Klepácek, I. \& Peterka, M. Prenatal development of rugae palatinae in mice: scanning electron microscopic and histologic studies. J. Craniofac. Genet. Dev. Biol., 7(2):169-89, 1987.

Rice, R.; Connor, E. \& Rice, D. P. Expression patterns of Hedgehog signalling pathway members during mouse palate development. Gene Expr. Patterns, 6(2):206-12, 2006.

Rosseto, M. C.; Palma, F. M.; Ferreira, R. I.; Pinzan, A. \& Vellini-Ferreira, F. Comparative study of dental arch width in plaster models, photocopies and digitized images. Braz. Oral Res., 23(2):190-5, 2009.

Sakamoto, M. K.; Nakamura, K.; Handa, J.; Kihara, T. \& Tanimura, T. Studies of variant palatal rugae in normal and corticosteroid-treated mouse embryos. Anat. Rec., 230(1):121-30, 1991.

Schultz, A. H. Palatine Ridges. In: Hofer, H.; Schultz, A. \& Starck, D. Primatologia. Vol. 3/ 1. New York, Karger, 1958. pp.127-38.

Schultz, A. H. The palatine ridges of primates. Contrib. Embryol., 33(213221):43-66, 1949.

Smith, T. M.; Lozanoff, S.; Iyyanar, P. P. \& Nazarali, A. J. Molecular signaling along the anterior-posterior axis of early palate development. Front. Physiol., 3:488, 2013.

Takanosu, M.; Amasaki, H.; Iwama, Y.; Ogawa, M.; Hibi, S. \& Suzuki, K. Epithelial cell proliferation and apoptosis in the developing murine palatal rugae. Anat. Histol. Embryol., 31(1):9-14, 2002.

Thomas, C. J. The prenatal developmental microscopic anatomy of the palatal rugae. J. Dent. Assoc. S. Afr., 39(8):527-33, 1984.

Welsh, I. C. \& O'Brien, T. P. Signaling integration in the rugae growth zone directs sequential SHH signaling center formation during the rostral outgrowth of the palate. Dev. Biol., 336(1):53-67, 2009.

Zarringhalam, M. Measuring palatal height in normal occlusion and malocclusions. J. Dent. Tehran Univ. Med. Sci., 1(4);39-42, 2004.

\author{
Corresponding author: \\ Dr. Ibrahim Alshahrani \\ Associate Professor \\ Orthodontics \\ Department of Pediatric Dentistry and Orthodontic Sciences \\ King Khalid University College of Dentistry \\ Abha \\ SAUDI ARABIA
}

Email: ishahrani@kku.edu.sa

Received: 24-11-2018

Accepted: 01-02-2019 